Article

\title{
Tensions in the Sustainability of Higher Education-The Case of Finnish Universities
}

\author{
Annina Lattu $(\mathbb{D}$ and Yuzhuo Cai *(D) \\ Faculty of Management and Business, Tampere University, 33014 Tampere, Finland; annina.lattu@tuni.fi \\ * Correspondence: yuzhuo.cai@tuni.fi
}

Received: 12 February 2020; Accepted: 28 February 2020; Published: 3 March 2020

check for updates

\begin{abstract}
Universities are increasingly engaged in marketization and are also expected to transform into more sustainable institutions and be change-agents pushing forward the movement of sustainable development. This article introduces an analytical framework originated by Hahn et al. (2015) for understanding tensions concerning corporate sustainability to the context of the Finnish university system in order to answer the following questions: What are the tensions relating to Finnish universities' social and economic sustainability, and what strategies might universities use to cope with these tensions? Through analyzing interviews with university managers and officials from the Ministry of Education and Culture in Finland, we find that Hahn et al.'s framework is generally applicable in analyzing tensions of sustainability in universities, and we identify six tensions relating to the sustainability of Finnish universities. The tensions are related to (1) academic leadership and management legitimacy, (2) regional political tensions and university profiling, (3) political power over the university system, (4) changing academic work and profession, (5) academic autonomy and the role of the state, and (6) the future role of the university institution. Moreover, the article discusses issues regarding how to adapt the framework of corporate sustainability to the context of higher education.
\end{abstract}

Keywords: sustainable universities; corporate sustainability; sustainability; tensions; integrative framework; Finnish universities

\section{Introduction}

In the book A Larger Sense of Purpose: Higher Education and Society, Shapiro [1] claims that universities have two roles: one is to serve the existing society, and the other is to challenge society to shape a better future. Today, the planetary crisis and sustainable development movement have raised new demands for higher education [2,3]. The 17 sustainable development goals (SDGs) adopted by the United Nations (UN) in the 2030 Agenda for Sustainable Development [4] underline a set of challenges paramount for universities to address [5]. The need for redefining a social contract between higher education and society [6], which was previously driven by mixed logics of being a social institution and being an industry institution [7], can now be argued to be driven by an additional force-the sustainable development movement, which champions the emerging concept of the "responsible university" [8].

The discussion regarding sustainable development and organizational change has gained momentum increasingly in higher education as well as in the corporate context [9]. This implies that universities have the same responsibility as any other organization to forward SDGs. In addition, special hopes are targeted at universities by different global institutions, e.g., the UN, which sees universities' roles as strategic knowledge producers and educators of future generations [5] (p. 31).

The scholarly discussion regarding sustainable development and organizational change and practices has been active in the field of business and management studies [9]. One can argue that 
the theories in the field of management studies regarding sustainability are more refined than in the field of higher education studies. In the research field of corporate sustainability, the win-win paradigm of perceiving sustainability as a profitable business for companies restricts sustainability solutions to conflict-free options with little ambition to fundamentally change core business practices for the sake of sustainable development [10] (p. 219). One of the prominent theories in the field is the integrative framework by Hahn et al. [11], which illustrates tensions related to sustainability in an organizational corporate context. The tensions [10] occur when an organization's objectives are in conflict regarding the three dimensions of sustainable development, namely ecological, social, and economic [12]. The framework by Hahn et al. [11] aims to illustrate these tensions and help companies see beyond the usual sustainability solutions aligned with the win-win paradigm.

The perspective on tensions is especially useful for understanding universities, which are increasingly operating in a hybrid context with contesting institutional logics [13]. Universities are organizations with huge expectations regarding their own organizational transformation [14] and their role in the global transformation toward sustainability [5]. While being loaded with expectations, it is crucial for universities to identify their tensions related to sustainability in order to contribute to their inner change processes as well as to the global change toward sustainable development, where they have a role as an abovementioned change-agent.

Several studies regarding the sustainable development of universities have been conducted in the field of higher education. Sustainability-oriented curricula and campus greening, i.e., minimizing of an organization's ecological footprint and societal sustainability agendas, are found to be areas in which universities should be leading as an example [14,15]. However, less attention has been given to the economic and social sustainability dimensions [16]. Also, there are as yet no appropriate frameworks for conceptualizing universities' organizational tensions regarding sustainable development in the field of higher education studies. That is why corporate sustainability, and especially the integrative framework [11], is relevant for introduction to the field of higher education studies.

One rare example of applying the integrative framework in the higher education context is the study by Sehnem et al. [17]. It analyses tensions of sustainability regarding establishing a new university campus of Unisul Sustentável-Pedra Branca in a sustainable neighborhood, with the Cidade Universitária Pedra Branca campus forming a conceptual framework using corporate sustainability theories from multiple authors.

The integrative framework [11] has not been fully introduced and adjusted to the higher education context. To fill this gap, we answer the following questions: What are the tensions relating to Finnish universities' social and economic sustainability, and what strategies might universities use to cope with these tensions? To approach the question, we will adjust the prominent framework by Hahn et al. [11] into the field of higher education. The modified framework will be tested in analyzing tensions related to Finnish universities' social and economic sustainability.

Finland has a dual model higher education system consisting of 13 universities and 23 universities of applied sciences [18]. Higher education policy has been a field of fierce political battles after Finnish universities were tied strongly to the state as part of social policy from 1960 onward $[19,20]$. The most significant and recent development in higher education policy is the Universities Act [21] law reform enacted in 2009. The new law enhanced universities' institutional autonomy, although "within a framework of greater accountability" [8] (p. 19) causing, strengthening, and also weakening several tensions in the Finnish higher education system [22]. Thus, the post-law reform Finland offers a fruitful context for testing the integrative framework by Hahn et al. [11], especially regarding social and economic sustainability.

The structure of the article follows. First, the analytical framework-the integrative framework by Hahn et al. [11] —is introduced. Then, the research methods of the study are explained, as well as the study itself. The article reviews the social and economic tensions related to Finnish universities' sustainable development and suggests strategies for coping with the tensions, after which it reflects 
upon the future application of the framework in the discussion section. Finally, the article concludes by answering the research question in the last section.

\section{Analytical Framework: The Integrative Framework by Hahn et al.}

It has been widely acknowledged in higher education literature that universities are increasingly confronting various tensions at both internal and external levels $[7,22,23]$. Higher education studies have also suggested various conceptual frameworks to understand both tensions and approaches to reconciling these tensions. For instance, these frameworks are included in studies on the dynamics of universities [13] and international joint education provisions [24], applying institutional logics [25], research on higher education institutions' missions [25], and applying the concept of academic drift [26]. However, as sustainability is entering the central agenda of higher education policy and university management, there is little research on tensions in universities from the perspective of sustainable development. Against such a challenge, we will develop an analytical framework for understanding tensions in sustainability and strategies of coping with the tensions in the university context, based on the conceptualization of corporate sustainability by Hahn, Pinkse, Preuss, and Figge [11].

Although the term "corporate sustainability" has been widely used, there is still no consensus on the definition of the concept; rather, common interpretation is built from the Brundtlandt Report [27] as "meeting the needs of a firm's direct and indirect stakeholders without compromising its ability to meet the needs of future stakeholders as well" [28] (p. 131). The discourse of corporate sustainability has focused more on the win-win paradigm and instrumental logics, where economic, environmental, and social sustainability aspects can be achieved simultaneously [11]. However, Hahn et al. [10] argue that tensions between these three dimensions are the rule rather than the exception, taking into account the multifaceted and complex nature of corporate sustainability. Hahn et al. [11] also argue that, following such a proposition, they develop an analytical framework for identifying tensions and approaches to managing them in a business setting.

The theoretical backbone of the framework is in the literature discussing strategic contradictions, tensions, and paradoxes [11,29-32]. As a paradox in this context, Hahn et al. refer to a situation in which oppositional elements co-exist [33] and in which individually accepted elements are inconsistent or incompatible together [34] (p. 563). The co-existing oppositional/conflicting elements are understood as two poles in a tension. Hahn et al. [11] argue that the ability of management to simultaneously pursue conflicting sustainability aspects is crucial when striving for corporate sustainability. Hahn et al.'s [11] framework is used to analyze two issues: what the primary tensions are (including oppositional poles in achieving sustainability) and what strategies are used to cope with the tensions. When dealing with the issues, Hahn et al.'s framework contemplates tensions that derive from the following aspects: (1) different understandings of the three dimensions of sustainability—environmental, social, and economic-across individual, organizational, and systemic levels; (2) different views on the change processes needed in order to become more sustainable; and (3) different views on the relevant temporal and spatial context of tensions illustrated in Figure 1 [11].

Regarding the first aspect, corporate sustainability is a multi-level concept [30], and thus the friction between different levels is one of the sources of tensions [11] (p. 302). The environmental, social, and economic dimensions of corporate sustainability have different connotations at different individual, organizational, and systemic levels of analysis. For example, tensions between organizational and systemic levels may arise if the organization's sustainability initiatives are not sufficient to address sustainability issues [11].

As an example of the occurrence of a sustainability tension regarding the second aspect, change could cause a disagreement between organizations in the transition toward renewable energy. Even though the technology might be developed sufficiently, the industry resists the change due to existing business models and alliances. Different kinds of vested interests incentivize organizations to act with different urgency levels toward sustainable development. [11,35]. 
Regarding the third aspect, contextual tensions stem from spatial and temporal elements of the context in which the transition toward sustainability takes place $[11,29,30]$. By the temporal element, Hahn et al. [11] refer to intergenerational equity for future generations. For example, if organizations' strategies overvalue short-term outcomes at the expense of long-term goals on certain other aspects-such as short-term financial performance versus long-term social performance-we are discussing a tension arising from the temporal context [11] (p. 303). The spatial element refers to intragenerational equity [11,36]. Different regions are at different development levels. An example of a tension arising from the spatial context could be a case in which a company operates in a developing country with different environmental or social standards [11]. The three perspectives provide a useful lens for identifying tensions and poles of paradoxes in achieving sustainability.

After the tensions are identified and understood profoundly, Hahn et al. [11] suggest three strategies for managing them by drawing on the insights from the literature on paradoxes in the field of management and organization theories. According to Poole and Van De Ven, paradoxes can be managed through opposition, spatial or temporal separation, or synthesis [11,29], where opposition represents an acceptance strategy and spatial and temporal, in turn, resolution strategies [11,29]. These three categories are the ones that Hahn et al. [11] suggest as the basis for the approach to managing tensions related to sustainability.

From these three approaches, the first type-acceptance strategy—refers to a situation in which decision makers differentiate the opposing two poles of a paradox, accept the resulting tensions, and maintain the paradox of seeking ways to live with it [11,32]. Compromise has not been sought; instead, the two poles of the contradiction are pursued simultaneously $[11,33,37]$. Improvisation is a characteristic of the opposition strategies coming from the everyday practice of the managers trying to "attend to both opposing domains of a paradox simultaneously while keeping the two poles apart" [11] (p. 300).

The other two strategies, resolution strategies, are used by managers to resolve a paradox "by spelling out the nature of the tensions between contrary positions" [11,29] (p. 300). Resolution implies "finding a means of meeting competing demands or considering divergent ideas simultaneously," instead of eliminating the tensions [11,29] (p. 300). Separation strategy means separating the two poles of the paradox spatially or temporally $[11,29]$. Spatial separation positions the poles on different levels, such as individual or societal, or different physical or social locations, whereas temporal separation divides the different poles into different points in time [11] (pp. 300-301). Synthesis strategy, in turn, refers to linking the opposing poles of a paradox together by a new perspective or element. Even though the mediating, overarching logic of combining the poles does not delete the paradox, it "offers a novel frame that can hold both opposing poles" [11] (p. 301).

As highlighted in the beginning of this section, tensions are a familiar topic in the higher education literature, and thus the integrative framework by Hahn et al. [11], contributing to the topic from a sustainability point of view, is relevant and interesting. Next, we will apply the integrative framework in the context of Finnish universities and test its validity in the higher education context, particularly in the case of Finland.

\section{Research Methods}

When investigating tensions in Finnish universities, we choose the method of phenomenology, as our research aims to increase general understanding of the phenomenon of tensions related to Finnish universities' sustainability. Since sustainability in the university context is a rather new phenomenon, phenomenology, with its exploration of meanings of new phenomena [38], was justified as the choice of methodology. Phenomenology focuses on peoples' experiences, perceptions of reality, and the meaning of those two [39]. The goal of the study was to understand interviewees' realities, construct organizational realities based on the similarities of the individual perceptions, and form a systemic view of the Finnish university system by comparing the individual and organizational perspectives to each other.

We used semi-structured interviews as a method for collecting data. The study had 11 interviewees, including: 
- Four members of university management from a Finnish capital region university-three Vice-rectors and a Dean;

- Four members of university management from a Finnish northern region university—one Rector and three Vice-rectors;

- Three senior officials from the Finnish Ministry of Education and Culture working with higher education and science policy.

The 11 interviews formed an appropriate sample, since the interview data reached a saturation point in the end of the analysis, and the same themes were repeated throughout the interview data.

Interviews were designed to ask about the tensions but left room for reinterpretation of the tensions. The interview was constructed so that it proceeded from individual value-level questions regarding interviewees' jobs, personal values, and organizational values to four question sub-sets regarding personnel and management, research and education, finance and administration, and the role of universities. All interviews ended with a final reflection, where the interviewee had the chance to raise issues not mentioned in the interview or comment on the interview process.

The study followed Heideggerian Smith's interpretive phenomenological analysis (IPA), where the focus is on how the interviewees make sense of their personal and social world and the meanings of these experiences [40] (p. 126). According to Merleau-Ponty [41] (p. vii), phenomenology is "the study of essence" focusing on the essential meaning of phenomena [42] (p. 189). The study aimed to understand interviewees' individual experiences and perceptions as well as to find similarities and differences between the three organizations, in this way getting to the essence of the tensions surrounding social and economic sustainability in the Finnish university system. Interviews were recorded, transcribed, and analyzed throughout the interview process, and the transcripts were analyzed using NVivo qualitative analysis software. Field notes were also used to mark down possible notable aspects and thoughts evoked by the interviews. The analysis followed IPA's [40] (p. 126) typical four stages, where first the transcript is read and analyzed and themes developed to capture the essence of the interviewees' experience. Then, the themes were analyzed and formed into master themes. Third, transcripts were analyzed with the master themes, and finally, the analytic interpretation of the data is presented. The analysis focused more on what was said than how it was said, still taking into account the characteristic interactions and the interview experiences, especially if they were in contradiction with the interview quotes.

Regarding the limitations, in any qualitative research method, there are intrinsic limitations, given the biased views of researchers. In our case, since we both are working in a Finnish university, there is a risk that, when interpretating the data, we might use our experience and presumptions as a filter. To be aware of such a risk, the data was mainly analyzed by the author, who is new to the university working environment, thus maximizing objective interpretation.

The tensions were analyzed in three categories-weak, somewhat significant, and significant. Tensions were categorized as weak if only one interviewee mentioned the tension. Somewhat significant tensions were categorized if two interviewees mentioned the tension. Significant tensions were categorized if three or more interviewees mentioned the tension. The categorization in detail can be seen in Appendix A.

\section{Tensions Related to Finnish Universities' Social and Economic Sustainability}

When identifying tensions around sustainability, we focus on the management level of the Finnish university system and particularly on its social and economic sustainability, because the most topical discussion in the field of higher education studies focuses on social and economic tensions- e.g., autonomy of universities [8,39] —and global competition among universities and its consequences [40,43].

Social sustainability was defined according to Magis and Shinn [44] (p. 16) as constituting four principles: human well-being, equity, democratic government, and democratic civil society. Economic sustainability was defined, in alignment with Repetto [45] (p. 10), as maintaining the 
economic systems in a state that enables our generation to live on the planet, maintaining and improving the resources for future generations to live at least equally well or even better.

In Finland, the Universities Act law reform professionalized university management from 2009 onward, and tensions arose from, for example, the increased distance between the university community and management [22] and the structural development measures incentivized by public funding [46] (pp. 15-17). Although universities gained more budgetary freedom, the Ministry of Education remained in the steering position of the university system [42]. With management issues being examined and the study being explorative in applying a new analytical framework to the field of higher education studies, its focus was guided to the management level of the Finnish university system.

Our research did not focus on the environmental dimension of the integrative framework, since the literature from the field of higher education studies from which the initial tensions were drawn focused so strongly on tensions related to social and economic dimensions. Since well-functioning universities are crucial to the paradigm shift toward more sustainable ways of living, we saw the social and economic tensions as the first thing to explore in our study, which can later be extended to be more holistic.

Altogether, six tensions were detected between the organizational level of the university leaders and the systemic level of the Ministry of Education and Culture. The tensions were (1) academic leadership and management legitimacy, (2) regional political tensions and university profiling, (3) political power over the university system, (4) changing academic work and profession, (5) academic autonomy and the role of the state, and (6) the future role of the university institution. These six tensions' poles and the literature they are based on can be seen in Table 1. Four tensions, excepting numbers 3 and 6 (which relate to change), occur between the organizational and systemic levels, in between objectives of social and economic sustainability.

The first tension, academic leadership and management legitimacy, refers to the increased distance between the academic community and university management $[22,43,46]$, which occurred after the Universities Act reform. Poles of the tension are economic sustainability objectives; striving for effective and centralized management versus social sustainability objectives; collegial, democratic academic management; and good social cohesion of the community. The tension was considered weak by the majority of the interviewees. Still, it is noteworthy, since this majority was the university leaders, whereas two out of three among the ministry officials detected this tension.

The second tension, regional political tensions and university profiling, refers to the tensions that occur due to profiling and structural development measures, which commenced after the 2009 law reform [22]. Competition for research funding is seen to lead to tensions inside academic communities [21,47], and this study supports it. In this tension, the social sustainability pole represents regional resiliency, and it is opposed to the economic sustainability pole: an effective and globally high-ranking national university system, which was the goal of the profiling measures.

The third tension, political power over the university system, was perceived as relevant by two out of four interviewees in the two universities and by one ministry official. In the literature, the political or policy drive for universities to respond to requirements from economic development versus universities' traditional social missions has been widely acknowledged [47]. In this tension, its poles are contextual and temporal. More precisely, the tension regards the duration of the political term in Finland. The rather short four-year period of a political term in the Finnish Parliament was perceived as a problem with respect to the long-termism of universities' nature. For instance, the results of the changes in university financing can be perceived only after years of development.

The fourth tension, changing academic work and profession, refers to the phenomenon of increasing the diversification of tasks of today's academic profession. Witchurch [48] describes this as the emergence of the "third space" in between academic and professional staff job descriptions. Also, sustainability-related competence can be inside the third space [49]. According to Aarrevaara and Hölttä [43], the increasing performance orientation in budgeting and other changes due to the 2009 law reform have affected the working environment of the university staff. Pinheiro et al. [18] mention that the current regulations do not necessarily guarantee fair working conditions for academics lacking 
sufficient resources for teaching and research or permanent work contracts. The social sustainability pole of the tension is the wellbeing of academics, which is in conflict with the economic sustainability objective; efficient universities excelling in global university rankings.

The fifth tension, academic autonomy and the role of the state, refers to the tension of the increased autonomy of universities, despite still being financially controlled by the state [18] (p. 7). There is no single definition for university autonomy [50], though it is one of the cornerstones of the university institution. According to Kohtamäki and Balbachevsky [50], the idea of autonomy has become to "serve the purposes of public policy" for national higher education policy purposes. In this tension, the poles are social sustainability objectives, autonomous universities, and academic freedom versus economic sustainability objectives.

Table 1. Tensions in Finnish universities between systemic and organizational levels.

\begin{tabular}{|c|c|c|}
\hline Name of Tension & $\begin{array}{l}\text { Identification of the Poles and Positioning } \\
\text { in the Framework from the Interviews }\end{array}$ & Reflections in the Literature \\
\hline $\begin{array}{l}\text { 1. Academic leadership } \\
\text { and management } \\
\text { legitimacy }\end{array}$ & $\begin{array}{l}\text { Economic sustainability: effective, centralized } \\
\text { management } \\
\text { vs. } \\
\text { Social sustainability: collegial, democratic } \\
\text { academic management }\end{array}$ & $\begin{array}{l}\text { Finnish higher education reform and its } \\
\text { effects: Aarrevaara \& Hölttä, 2008; Pinheiro et } \\
\text { al., } 2014 \\
\text { Assessment of the Universities Act } \\
2009 \text { Ministry of Education and Culture, } 2016\end{array}$ \\
\hline $\begin{array}{l}\text { 2. Regional political } \\
\text { tensions and university } \\
\text { profiling }\end{array}$ & $\begin{array}{l}\text { Social sustainability: regional resiliency } \\
\text { vs. } \\
\text { Economic sustainability: effective and } \\
\text { excelling national university system }\end{array}$ & $\begin{array}{l}\text { Discussion of the tensions in profiling in } \\
\text { Finland: Pinheiro et al., 2014, Tirronen, } 2015 \\
\text { Assessment of the Universities Act } \\
2009 \text { Ministry of Education and Culture, } 2016\end{array}$ \\
\hline $\begin{array}{l}\text { 3. Political power over } \\
\text { the university system }\end{array}$ & $\begin{array}{l}\text { Temporal tension; Short-termism: the } \\
\text { four-year period of members of the Finnish } \\
\text { Parliament, political parties in power } \\
\text { vs. } \\
\text { Long-termism: universities' long-term nature } \\
\text { regarding change and contributions }\end{array}$ & $\begin{array}{l}\text { Political pressure from economic } \\
\text { development versus universities' traditional } \\
\text { social missions: Cai \& Liu, } 2020\end{array}$ \\
\hline $\begin{array}{l}\text { 4. Changing academic } \\
\text { work and profession }\end{array}$ & $\begin{array}{l}\text { Social sustainability: wellbeing of academics } \\
\text { and ability to create high quality research } \\
\text { vs. } \\
\text { Economic sustainability: need for efficiency, } \\
\text { increasing demands on researchers due to } \\
\text { declining financial resources }\end{array}$ & $\begin{array}{l}\text { Change of academic profession: } \\
\text { Withchurch, 2012; Aarrevaara \& Hölttä, 2008; } \\
\text { Pinheiro et al., } 2014\end{array}$ \\
\hline $\begin{array}{l}\text { 5. Academic autonomy } \\
\text { and the role of the state }\end{array}$ & $\begin{array}{c}\text { Social sustainability: autonomous } \\
\text { universities and academic freedom } \\
\text { vs. } \\
\text { Economic sustainability: national need for } \\
\text { efficient universities and research relevant for } \\
\text { economic growth }\end{array}$ & $\begin{array}{l}\text { Autonomy of Finnish universities: Kohtamäki } \\
\text { \& Balbachevsky, 2018; Pinheiro et al., } 2014\end{array}$ \\
\hline $\begin{array}{l}\text { 6. The future role of the } \\
\text { university institution }\end{array}$ & $\begin{array}{l}\text { Change-related tension; future development } \\
\text { of university institution } \\
\text { vs. } \\
\text { Future competitors overruling university } \\
\text { institution }\end{array}$ & $\begin{array}{c}\text { Development of knowledge- } \\
\text { production modes } 1 \text { and 2, post-normal } \\
\text { science: Gibbons et al., 1994; Ravetz, } 1999 \\
\text { Development of university institution: } \\
\text { Hammershøj, } 2019\end{array}$ \\
\hline
\end{tabular}

The sixth tension, the future role of the university institution, is a tension related to different perspectives on a change process, namely that within the university institution. The development of knowledge production from the traditional academic Mode 1 to a more participatory and interdisciplinary Mode 2 [51] and the discussion on post-normal science with an extended peer community [52] have been topics of discussion among the academic community for quite some time. Also, the development of university institutions has been discussed by many (e.g., by Hammershøj [53]) painting a perfect-storm scenario for universities, with the "AirBnb of higher education" threatening to take over if the employability needs of society are not acted upon. The poles of the tension are the change trajectories of future development of the university institution versus the future competitors overruling university institutions. Only one ministry official and two academic leaders from each 
institution detected the tension. Neither university leaders nor the ministry officials sensed many threats or competitors to university institutions' dominant position in the field of higher education.

\section{Strategies for Managing Tensions in Sustainability}

In this section, we reflect on the possible coping strategies for the six tensions detected in the study by using the integrative framework by Hahn et al. [11] and its examples of coping strategies. Although ambitious, this practice aims to illustrate possible coping strategies and simultaneously how the integrative framework can be utilized in the future. Even though our interview data did not comprise enough insights for suggesting certain coping strategies, we try to reflect the possible strategies for the six tensions between the organizational and systemic levels. We find that one tension can be coped with using different strategies (Table 2).

Table 2. Different coping strategies for the six social tensions regarding universities' social and economic sustainability.

\begin{tabular}{|c|c|c|c|}
\hline Tensions & Acceptance Strategies & $\begin{array}{l}\text { Resolution Strategies } \\
\text { Separation Strategies }\end{array}$ & Synthesis Strategies \\
\hline $\begin{array}{l}\text { 1. Academic leadership } \\
\text { and management } \\
\text { legitimacy }\end{array}$ & $\begin{array}{l}\text { Simultaneously pursuing } \\
\text { academic leadership and } \\
\text { collegial } \\
\text { decision-making-e.g., } \\
\text { a management training for the } \\
\text { academic leaders—-while } \\
\text { ensuring representation of the } \\
\text { academic cimmunity in } \\
\text { decision making }\end{array}$ & $\begin{array}{l}\text { Separating the active members } \\
\text { of the academic community to } \\
\text { discuss and later present } \\
\text { insights to the top } \\
\text { management }\end{array}$ & $\begin{array}{c}\text { A policy fostering members of } \\
\text { the university being able to } \\
\text { participate in the decision } \\
\text { making }\end{array}$ \\
\hline $\begin{array}{l}\text { 2. Regional political } \\
\text { tensions and university } \\
\text { profiling }\end{array}$ & $\begin{array}{l}\text { Encouraging cooperation for } \\
\text { regional resiliency and for } \\
\text { efficient universities }\end{array}$ & $\begin{array}{l}\text { Addressing regional resiliency } \\
\text { and efficiency at different } \\
\text { levels or groups in the ministry }\end{array}$ & $\begin{array}{l}\text { Develop an institution to } \\
\text { mitigate the tensions between } \\
\text { regional resilience and } \\
\text { national efficiency }\end{array}$ \\
\hline $\begin{array}{l}\text { 3. Political power over } \\
\text { the university system }\end{array}$ & $\begin{array}{l}\text { An arena for dialogue for } \\
\text { politicians and university } \\
\text { leaders and policy-makers }\end{array}$ & $\begin{array}{l}\text { Long-term orientation a core } \\
\text { responsibility of the } \\
\text { university's top management }\end{array}$ & $\begin{array}{l}\text { Legislative change: university } \\
\text { funding models impossible to } \\
\text { change in one political term }\end{array}$ \\
\hline $\begin{array}{l}\text { 4. Changing academic } \\
\text { work and profession }\end{array}$ & $\begin{array}{l}\text { Incrementally introduce new } \\
\text { practices as part of researchers' } \\
\text { job while taking care of } \\
\text { wellbeing }\end{array}$ & $\begin{array}{l}\text { Organizing workshops, } \\
\text { trainings, and space and time } \\
\text { for dialogue dealing with the } \\
\text { stress and anxiety caused by } \\
\text { the new pressures. } \\
\text { Also organizing similar } \\
\text { initiatives for discussing and } \\
\text { ideating the future of the } \\
\text { academic profession and } \\
\text { learning new practical skills } \\
\text { related to it }\end{array}$ & $\begin{array}{l}\text { Engaging in an institutional } \\
\text { change and actively shaping } \\
\text { expectations optimistic about } \\
\text { the future and toward the } \\
\text { changing academic profession. }\end{array}$ \\
\hline $\begin{array}{l}\text { 5. Academic autonomy } \\
\text { and the role of the state }\end{array}$ & $\begin{array}{l}\text { Cooperation between Ministry } \\
\text { of Education and universities } \\
\text { for solutions }\end{array}$ & $\begin{array}{l}\text { Ministry and universities } \\
\text { discuss autonomy issues first } \\
\text { separately and then together }\end{array}$ & $\begin{array}{l}\text { Establish an institution for } \\
\text { discussing the tension of states' } \\
\text { control on the university } \\
\text { system }\end{array}$ \\
\hline $\begin{array}{l}\text { 6. The future role of the } \\
\text { university institution }\end{array}$ & $\begin{array}{l}\text { Bringing together all the } \\
\text { stakeholders to discuss the } \\
\text { different futures of university } \\
\text { and science }\end{array}$ & $\begin{array}{l}\text { Different groups discussing } \\
\text { different sub-topics of the } \\
\text { future of university and } \\
\text { science }\end{array}$ & $\begin{array}{c}\text { Active and radical reflection of } \\
\text { the future of university } \\
\text { institution }\end{array}$ \\
\hline
\end{tabular}

For the first tension regarding academic leadership and management legitimacy, a possible acceptance strategy could be simultaneously pursuing academic leadership and collegial decision-making. For instance, the ministry level could organize professional top-management trainings for academic leaders, and in this way enhance modern, determined but participatory academic leadership. At the same time, the universities could involve the academic community in decision-making by ensuring representation of the staff in decision-making processes-for example, 
offering a seat in the board of the university. A possible separation strategy could be forming a group of active members of the university community to discuss separately and present their insights and ideas to the top management. A synthesis strategy, i.e., linking the opposing poles together, could be a new policy that would ensure that the members of the university community are being able to participate in decision making.

For the second tension, "regional political tensions and university profiling," an acceptance strategy could be encouraging cooperation between parties with opposing interests regarding both efficiency and regional resiliency to foster mutual understanding of the tension and work toward creative solutions. A separation strategy could be addressing regional resiliency and efficiency at different levels or groups in the ministry (which is still in the steering position of the university system) to ensure that the steering mechanisms enable both social and economic sustainability dimensions. A synthesis strategy could be to develop an institution to mitigate the tensions between regional resilience and national efficiency by, for instance, facilitating collaboration between universities and enhancing top-performing university units.

For the third tension, "political power over the university system," one kind of acceptance strategy could be ensuring that politicians and university leaders and policy-makers have an arena for dialogue. The dialogue would educate politicians about the characteristics of the university system and provide university leaders insights for acting in the political climate. Separation strategy, on the other hand, could separate the poles of the universities to make long-term orientation a core responsibility of the university top management and reward universities for reaching their own significant long-term goals. Our suggestion for a synthesis strategy could be a legislative change for ensuring that university funding models and policy frameworks cannot be changed significantly in one political term. This way, the state should also align long-term strategy regarding extensive budgetary changes, which would make funding more predictable for the universities.

For the fourth tension of changing academic work and profession, one potential acceptance strategy could be to incrementally and sustainably introduce new practices, while determinedly taking care of the coping of the academic staff. The poles could be separated with a separation strategy of organizing workshops, trainings, and space and time for dialogue dealing with the stress and anxiety caused by the new pressures. On the other hand, there could be similar initiatives for discussing and ideating the future of the academic profession and learning new practical skills related to it. We suggest for the synthesis strategy engaging in an institutional change and actively shaping expectations to be optimistic about the future and toward the changing academic profession.

For the fifth tension of academic freedom and autonomy, we suggest an acceptance strategy, where cooperation between the Ministry of Education and universities would be increased in order to foster mutual understanding of the tension and work toward creative solutions. A possible separation strategy could be to separate the poles of the tension (ministry and universities) to discuss their perspectives on autonomy issues, which would later be discussed together. An example of a synthesis strategy could be to establish a group or institution for mitigating the tension of academic autonomy and states' control of the university system. The institution should not be under the ministry of education and it should be as far away from the state control orbit as possible, which would be tricky.

For the sixth tension, the role of university institutions in the future, we suggest an acceptance strategy of bringing together all the stakeholders, including the small emerging actors, of academic research in Finland and the Finnish universities to discuss the future of university. For the separation strategy, we suggest separating the poles of the tensions, different groups discussing different topics regarding the future of university. This can be done inside universities or outside universities. For the synthesis strategy, we suggest that the universities and the Ministry of Education actively reflect the future of the university institution with genuinely different scenarios and carry out their own vision of the university institution in a future-oriented manner. 


\section{Discussion: How the Integrative Framework and Corporate Sustainability Can Be Used in the University Context}

This section outlays the limitations of the study by contemplating what can be learned from the case of Finland, when applying the integrative framework in the future. Also, the differences and similarities regarding the university context in comparison to the corporate context are discussed along with suggestions for future research.

\subsection{What Can Be Learned from the Finland Case Study?}

One may rightly ask, what is the value of the integrative framework on the Finnish, or any, university system regarding sustainability, if all its dimensions are not taken into account simultaneously? In this case study of Finland, the decision to study only social and economic tensions is justified with the urgency and scale of the social and economic tensions. This decision, however, prevents perception of the holistic sustainability possibilities, where, like stated previously in the text, environmental sustainability is the driving force and crucial element-the motive for the study itself. The dimension of environmental sustainability should be included in the study, so that the results would be holistic and provide the analytical lens that saves managers from making decisions belonging to the instrumental logic paradigm [10]. On the other hand, this type of research design can work as a basis for further analysis, where the environmental dimension is then taken into account. It does have to be taken into account at some point, since that is the overall goal of the whole analysis.

Another aspect worth paying attention to is the question of how the tensions of sustainability are detected. In the case study, the six tensions were formed based on literature, which then formed the basis of the semi-structured interviews. This way, the interviewees were already somewhat limited with their answers. One can ponder what kind of tensions would have emerged more inductively from the minds of the university leaders and ministry officials without being primed with the themes of the six initial tensions. It is up for the researcher to decide in what manner to narrow the scope of the tensions depending on whether the objective of the study is to explore all the possible tensions, or to study tensions that are known beforehand to some extent.

Studying these tensions puts a lot of weight on the definitions of sustainability used by the researcher. As discussed [9], the definitions of sustainability are still in the development phase and researchers are responsible for providing clear explication as to why and how a tension is one of social, economic, or environmental sustainability. In the case of Finland, the link of the six tensions to social and economic sustainability exists, but can be more or less complicated to grasp, for example in the second tension. Regional political tensions and university profiling are defined as a tension of social sustainability because of a university institution's role in building social cohesion and enabling sustainable development [5]. Another view of the tension could be spatial, since the question is also about regional versus centralized emphasis of the university system.

\subsection{Strategies for Managing Tensions in Sustainability}

Among the practical implications and societal values of the integrative framework [11] are the strategies for managing the tensions of sustainability. The opposition, spatial or temporal separation, and synthesis strategies [11] are built on the literature on paradoxes. The two poles form a paradox and are used as in Section 2, by opposition, separation, and synthesis to manage the tension.

The focus of the study is important when choosing what part of the integrative framework [11] is applied as an analytical lens. In the Finland case study, levels are used as the lens, almost omitting the dimensions of change and context. Depending on the focus of the study, the dimensions of context and change, or all three dimensions, might be suitable for application to a greater extent. The tensions of this study were explored in order to study what kinds of tensions of social and economic sustainability exist in the first place. The scope of the study was not targeted at any level, and thus the tensions are very broad, as are the suggested coping strategies. For the future application of the integrative framework, the narrower the scope, the better the results for forming coping strategies. 


\subsection{Suggestions for Future Research}

Besides integrating the environmental dimensions to the analysis, there are other suggestions to be made based on the limitations of this study. First, as the primary purpose of study is to introduce Hahn et al.'s [11] analytical framework of tensions in corporate sustainability into the field of higher education studies, a relatively small number of interviews was chosen for empirical analysis. Thus, the empirical findings of the study need to be further verified and extended to a larger context in future studies.

Second, the study focused on the tensions between the organizational and systemic levels represented by the ministry officials and university managers. In future research, it would be interesting to expand the focus of the study to the individual and organizational level of universities. In addition to university managers, academics from different fields of research as well as administrators could be included in the group of interviewees to study the possible differences of perceptions regarding social, environmental, and economic sustainability.

\section{Conclusions}

The scholarly discussion regarding sustainable development and related organizational changes has been active and more refined in the field of business and management studies [9], compared to the field of higher education research. Although sustainability and sustainable development of universities has become a popular topic, less attention has been given to deep analyses of the economic and social dimensions of sustainability [16], and there are yet no appropriate frameworks for conceptualizing universities' organizational tensions regarding sustainable development. This paper has applied a prominent analytical framework on corporate sustainability by Hahn et al. [11] to the higher education context, and approved the usefulness of the framework in analyzing the tensions relating to Finnish universities' social and economic sustainability as well as strategies to be used to cope with these tensions. Specifically, the tensions found in this study are related to (1) academic leadership and management legitimacy, (2) regional political tensions and university profiling, (3) political power over the university system, (4) changing academic work and profession, (5) academic autonomy and the role of the state, and (6) the future role of the university institution. In addition, we explored the coping strategies for each tension in Section 5.

We suggest the following five issues to be considered when applying the integrative framework. First, one should take into consideration all three types of tensions-social, economic, and environmental-when striving for the holistic view on different potential strategic choices regarding sustainability, and one should not to be restricted by the instrumental view on sustainability. Second, the aspect of whether the goal of the research is to explore new tensions or study acknowledged tensions should be taken into account in the research design. Third and fourth, the definition of tension related to societal, environmental, and economic sustainability should be explicit, as should be the different poles of the tension. Finally, the dimensions of the integrative framework-change, context, and levels—can be applied by the researcher to the part suitable for the tensions at hand.

Although marketized and sharing similarities with corporations, universities are different kinds of organizations with different objectives, organizational structures, and purposes. This has to be taken into account in general when applying the integrative framework or other frameworks from the field of corporate sustainability to the university context. The level of resemblance to a corporation depends a lot upon the university being studied. How much of a quasi-business organization [54] does the university or universities in question resemble? Although universities are increasingly marketized [55], they do not function by the private market logic but are, especially in the Nordic countries, financed by the state [56]. A corporation's duty is to make a profit for its owners [55], while the university's duty in Finland is enacted in the law, comprised of research, education, and third mission tasks [21].

The integrative framework [11] from the field of corporate sustainability is a relevant framework for the higher education context, since universities have to change toward more sustainable organizational practices themselves. In addition, universities are expected to be active change-agents contributing to the sustainable development movement by educating the future workforce as well as producing 
relevant and crucial knowledge regarding the future of humanity [5]. This article was an initial step toward integrating corporate sustainability literature into the discussion of the sustainability of higher education institutions.

Author Contributions: Conceptualization, Y.C.; methodology, A.L.; data curation: A.L.; formal analysis, A.L.; writing — original draft preparation, A.L.; writing — review and editing, Y.C. All authors have read and agreed to the published version of the manuscript.

Funding: The APC was funded by the authors.

Acknowledgments: The authors wish to thank the peer-reviewers of this paper for valuable comments.

Conflicts of Interest: The authors declare no conflict of Interest. The funders had no role in the design of the study; in the collection, analyses, or interpretation of data; in the writing of the manuscript, or in the decision to publish the results.

\section{Appendix A}

Table A1. Perception of the tensions in each organization.

\begin{tabular}{|c|c|c|c|}
\hline Tension & $\begin{array}{c}\text { Ministry of Education } \\
\text { and Culture } \\
\text { Level of the Tension: } \\
*=\text { Weak Tension, } \\
\text { 1 Interviewee Mentioned } \\
* * \text { = Somewhat } \\
\text { Significant Tension, } \\
2 \text { Interviewees } \\
\text { Mentioned } \\
\text { *** = Significant Tension, } \\
3+\text { Interviewees } \\
\text { Mentioned }\end{array}$ & $\begin{array}{c}\text { Northern University } \\
\text { Level of the Tension: } \\
*=\text { Weak Tension, } \\
1 \text { Interviewee Mentioned } \\
* *=\text { Somewhat } \\
\text { Significant Tension, } \\
2 \text { Interviewees } \\
\text { Mentioned } \\
* * * \text { Significant Tension, } \\
3 \text { + Interviewees } \\
\text { Mentioned }\end{array}$ & $\begin{array}{c}\text { Capital Region } \\
\text { University } \\
\text { Level of the Tension: } \\
*=\text { Weak Tension, } \\
1 \text { Interviewee Mentioned } \\
* *=\text { Somewhat } \\
\text { Significant Tension, } \\
2 \text { Interviewees } \\
\text { Mentioned } \\
* * *=\text { Significant Tension, } \\
3 \text { + Interviewees } \\
\text { Mentioned }\end{array}$ \\
\hline $\begin{array}{l}\text { 1. Academic leadership } \\
\text { and management } \\
\text { legitimacy }\end{array}$ & $\begin{array}{c}\text { ** Somewhat significant } \\
\text { tension }\end{array}$ & ${ }^{*}$ Weak tension & * Weak tension \\
\hline $\begin{array}{l}\text { 2. Regional political } \\
\text { tensions and university } \\
\text { profiling }\end{array}$ & * Weak tension & $* * *$ Significant tension & $\begin{array}{l}* * \text { Somewhat significant } \\
\text { tension }\end{array}$ \\
\hline $\begin{array}{l}\text { 3. Political power over } \\
\text { the university system }\end{array}$ & * Weak tension & $\begin{array}{c}* \text { Somewhat significant } \\
\text { tension }\end{array}$ & $\begin{array}{c}* \text { Somewhat significant } \\
\text { tension }\end{array}$ \\
\hline $\begin{array}{l}\text { 4. Changing academic } \\
\text { work and profession }\end{array}$ & * Weak tension & $* * *$ Significant tension & $* * *$ Significant tension \\
\hline $\begin{array}{l}\text { 5. Academic autonomy } \\
\text { and the role of the state }\end{array}$ & * Weak tension & $* * *$ Significant tension & $\begin{array}{l}\text { ** Somewhat significant } \\
\text { tension }\end{array}$ \\
\hline $\begin{array}{l}\text { 6. The future role of the } \\
\text { university institution }\end{array}$ & * Weak tension & $\begin{array}{c}\text { ** Somewhat significant } \\
\text { tension }\end{array}$ & $\begin{array}{c}* * \text { Somewhat significant } \\
\text { tension }\end{array}$ \\
\hline
\end{tabular}

\section{References}

1. Shapiro, H.T.; Shapiro, H.T.T. A Larger Sense of Purpose: Higher Education and Society; Princeton University Press: Princeton, NJ, USA, 2009; ISBN 978-1-4008-2674-2.

2. Rockström, J.; Steffen, W.; Noone, K.; Persson, Å.; Chapin, F.S.I.; Lambin, E.; Lenton, T.; Scheffer, M.; Folke, C.; Schellnhuber, H.J.; et al. Planetary Boundaries: Exploring the Safe Operating Space for Humanity. Ecol. Soc. 2009, 14, 32. [CrossRef]

3. Mazzucato, M. Mission-Oriented Research \& Innovation in the European Union: A Problem-Solving approach to Fuel Innovation-Led Growth; European Commission: Brussels, Belgium, 2018.

4. United Nations. Transforming Our World: The 2030 Agenda for Sustainable Development 2015; United Nations: New York, NY, USA, 2015. 
5. Wells, P.J. Unesco's Introduction: The Role of Higher Education Institutions Today. In Higher Education in the World 6. Towards a Socially Responsible University: Balancing the Global with the Local; Grau, F.X., Goddard, J., Hall, B.L., Hazelkorn, E., Tandon, R., Eds.; Global University Network for Innovation (GUNi): Barcelona, Spain, 2017.

6. Maassen, P. A New Social Contract for Higher Education? In Higher Education in Societies; Sense Publishers: Boston, MA, USA, 2014; pp. 33-50.

7. Gumport, P.J. Academic restructuring: Organizational change and institutional imperatives. High. Educ. Dordr. 2000, 39, 67-91. [CrossRef]

8. Sørensen, M.; Geschwind, L.; Kekäle, J.; Pinheiro, R. (Eds.) The Responsible University: Exploring the Nordic Context and Beyond; Palgrave Macmillan: London, UK, 2019; ISBN 978-3-030-25645-6.

9. Swarnapali, N.C. Corporate sustainability: A Literature review. J. Account. Res. Educ. 2017, 1, 1-15.

10. Hahn, T.; Figge, F.; Pinkse, J.; Preuss, L. Trade-offs in corporate sustainability: You can't have your cake and eat it. Bus. Strategy Environ. 2010, 19, 217-229. [CrossRef]

11. Hahn, T.; Pinkse, J.; Preuss, L.; Figge, F. Tensions in Corporate Sustainability: Towards an Integrative Framework. J. Bus. Ethics 2015, 127, 297-316. [CrossRef]

12. Elkington, J. Partnerships from Cannibals with Forks: The Triple Bottom Line of 21st-Century Business. Environ. Qual. Manag. 1998, 8, 37-51. [CrossRef]

13. Lepori, B. Universities as Hybrids: Applications of Institutional Logics Theory to Higher Education. In Theory and Method in Higher Education Research; Emerald: Bingley, UK, 2016; pp. 245-264.

14. Ralph, M.; Stubbs, W. Integrating environmental sustainability into universities. High Educ 2014, 67, 71-90. [CrossRef]

15. Amaral, L.P.; Martins, N.; Gouveia, J.B. Quest for a sustainable university: A review. Int. J. Sustain. High. Educ. 2015, 16, 155-172. [CrossRef]

16. Ruiz-Mallén, I.; Heras, M. What Sustainability? Higher Education Institutions' Pathways to Reach the Agenda 2030 Goals. Sustainability 2020, 12, 1290. [CrossRef]

17. Sehnem, S.; Martignago, G.; Pereira, S.C.F.; Jabbour, C.J.C.; Sehnem, S.; Martignago, G.; Pereira, S.C.F.; Jabbour, C.J.C. Sustainable Management at a University in Light of Tensions of Sustainability Theory. Rev. Adm. Contemp. 2019, 23, 182-206. [CrossRef]

18. Ministry of Education of Finland Higher Education Institutions and Science Agencies. Available online: https://minedu.fi/en/heis-and-science-agencies (accessed on 24 February 2020).

19. Lampinen, O. Suomen Koulutusjärjestelmän Kehitys; Gaudeamus: Helsinki, Finland, 2000.

20. Kivinen, O.; Rinne, R.; Ketonen, K. Yliopiston Huomen: Korkeakoulupolitiikan Historiallinen Suunta Suomessa; Hanki ja jää: Tampere, Finland, 1993.

21. Ministry of Education of Finland Universities Act: 558/2009. Available online: http://www.finlex.fi/fi/laki/ smur/2009/20090558 (accessed on 5 January 2017).

22. Pinheiro, R.; Geschwind, L.; Aarrevaara, T. Nested tensions and interwoven dilemmas in higher education: The view from the Nordic countries. Camb. J. Reg. Econ. Soc. 2014, 7, 233-250. [CrossRef]

23. Cai, Y. Confronting the Global and the Local-A Case Study of Chinese Higher Education. Tert. Educ. Manag. 2004, 10, 157-169.

24. Zheng, G.; Cai, Y.; Ma, S. Towards an analytical framework for understanding the development of a quality assurance system in an international joint programme. Eur. J. High. Educ. 2017, 7, 243-260. [CrossRef]

25. Thornton, P.H.; Lounsbury, M.; Ocasio, W. The Institutional Logics Perspective: A New Approach to Culture, Structure and Process, 1st ed.; Oxford University Press: Oxford, NY, USA, 2012; ISBN 978-0-19-960194-3.

26. Burgess, T. The Shape of Higher Education; Cornmarket Press: London, UK, 1972.

27. United Nations World Commission on Environment and Development, Ed. Report of the World Commission on Environment and Development Our Common Future; Oxford University Press: Oxford, NY, USA, 1987.

28. Dyllick, T.; Hockerts, K. Beyond the business case for corporate sustainability. Bus. Strategy Environ. 2002, 11, 130-141. [CrossRef]

29. Poole, M.S.; Van de Ven, A.H. Using Paradox to Build Management and Organization Theories. AMR 1989, 14, 562-578. [CrossRef] 
30. Ford, J.D.; Ford, L.W. Logics of Identity, Contradiction, and Attraction in Change. AMR 1994, 19, 756-785. [CrossRef]

31. Lewis, M.W. Exploring Paradox: Toward a More Comprehensive Guide. AMR 2000, 25, 760-776. [CrossRef]

32. Smith, W.K.; Lewis, M.W. Toward a Theory of Paradox: A Dynamic equilibrium Model of Organizing. AMR 2011, 36, 381-403.

33. Clegg, S.R.; da Cunha, J.V.; e Cunha, M.P. Management Paradoxes: A Relational View. Hum. Relat. 2002, 55, 483-503. [CrossRef]

34. Young, W.; Tilley, F. Can businesses move beyond efficiency? The shift toward effectiveness and equity in the corporate sustainability debate. Bus. Strategy Environ. 2006, 15, 402-415. [CrossRef]

35. Basu, K.; Palazzo, G. Corporate Social Responsibility: A Process Model of Sensemaking. AMR 2008, 33, 122-136. [CrossRef]

36. Okereke, C. Global environmental sustainability: Intragenerational equity and conceptions of justice in multilateral environmental regimes. Geoforum 2006, 37, 725-738. [CrossRef]

37. Beech, N.; Burns, H.; Caestecker, L.; de MacIntosh, R.; MacLean, D. Paradox as invitation to act in problematic change situations. Hum. Relat. 2004, 57, 1313-1332. [CrossRef]

38. Finlay, L. Debating Phenomenological Research Methods. Phenomenol. Pract. 2009, 3, 6-25. [CrossRef]

39. Langdridge, D. Phenomenological Psychology: Theory, Research and Method; Pearson Education: Harlow, UK, 2007; ISBN 978-0-13-196523-2.

40. Gill, M.J. The Possibilities of Phenomenology for Organizational Research. Organ. Res. Methods 2014, 17, 118-137. [CrossRef]

41. Merleau-Ponty, M. Phenomenology of Perception; Taylor \& Francis: Abingdon, UK, 2002; ISBN 978-1-134-47008-2.

42. Kafle, P. Hermeneutic phenomenological research method simplified. Bodhi: Interdiscip. J. 2011, 5, $181-200$. [CrossRef]

43. Hölttä, S.; Nuotio, J. Academic leadership in a self-regulative environment: A challenge for finnish universities. Tert. Educ. Manag. 1995, 1, 12-20. [CrossRef]

44. Magis, K.; Shinn, C. Emergent principles of social sustainability. In Understanding the Social Dimension of Sustainability; Routledge: Abingdon, UK, 2008; ISBN 978-0-203-89297-8.

45. Repetto, R. The Global Possible: Resources, Development, and the New Century; Yale University Press: New Haven, CT, USA, 1986.

46. Ministry of Education and Culture; Group Owal. Yliopistolakiuudistuksen Vaikutusten Arviointi; Ministry of Education and Culture: Helsinki, Finland, 2016; ISBN 978-952-263-420-7.

47. Cai, Y.; Liu, C. The Role of University as Institutional Entrepreneur in Regional Innovation System: Towards an Analytical Framework. In Examining the Role of Entrepreneurial Universities in Regional Development; IGI Global: Hershey, PA, USA, 2020; ISBN 978-1-79980-174-0.

48. Withchurch, C. Reconstructing Identities in Higher Education: The Rise of Third Space Professionals; ResearchGate: Berlin, Germany, 2012; ISBN 978-0-203-09830-1.

49. Chambers, D.P.; Walker, C. Sustainability as a Catalyst for Change in Universities: New Roles to Meet New Challenges. In Challenges in Higher Education for Sustainability; Davim, J.P., Filho, W.L., Eds.; Management and Industrial Engineering; Springer International Publishing: Cham, Switzerland, 2016; ISBN 978-3-319-23704-6.

50. Kohtamäki, V.; Balbachevsky, E. University autonomy from past to present. In Theoretical and Methodological Perspectives on Higher Education Management and Transformation; University Press: Tampere, Finland, 2018; ISBN 978-952-03-0843-8.

51. Gibbons, M.; Limoges, C.; Nowotny, H.; Schwartzman, S.; Scott, P.; Trow, M. The New Production of Knowledge: The Dynamics of Science and Research in Contemporary Societies; SAGE: Sauzendeaux, CA, USA, 1994; ISBN 978-1-4462-6587-1.

52. Ravetz, J. The post-normal science of precaution. Futures 2004, 36, 347-357. [CrossRef]

53. Hammershøj, L.G. The perfect storm scenario for the university: Diagnosing converging tendencies in higher education. Futures 2019, 111, 159-167. [CrossRef]

54. Marginson, S. The Global Construction of Higher Education Reform. In The Handbook of Global Education Policy; John Wiley \& Sons Ltd.: Hoboken, NJ, USA, 2016. 
55. Hahn, T.; Figge, F. Beyond the Bounded Instrumentality in Current Corporate Sustainability Research: Toward an Inclusive Notion of Profitability. J. Bus. Ethics 2011, 104, 325-345. [CrossRef]

56. Pinheiro, R. Reforms, Organizational Change and Performance in Higher Education; Springer: Berlin/Heidelberg, Germany, 2019; ISBN 978-3-030-11738-2.

(C) 2020 by the authors. Licensee MDPI, Basel, Switzerland. This article is an open access article distributed under the terms and conditions of the Creative Commons Attribution (CC BY) license (http://creativecommons.org/licenses/by/4.0/). 